\title{
Antifungal Activity of Some New Binuclear Complexes
}

\author{
Z. F. Dawood" \\ W.A Y. Al-Khafaf ** \\ M.Y. Muhammad**
}

Date of acceptance $1 / 3 / 2010$

\begin{abstract}
Three complexes of copper(II) and iron(II) with mixed ligands acetylacetonebis(thio-semicarbazone)- $\mathrm{ABTSH}_{2}$ and benzaldazine- BA have been prepared and characterized using different physico-chemical techniques including the determination of metal contents, mole-cular weight, measurement of molar conductivity, magnetic moment, molar refraction, infrared and electronic spectra. Accordingly, octahedral complexes having general formulaes $\left[\mathrm{Cu}_{2}(\mathrm{ABTSH})_{2}(\mathrm{BA})_{2} \mathrm{Cl}_{2}\right] \mathrm{Cl}_{2}$ and $\left[\mathrm{M}_{2}\left(\mathrm{ABTSH}_{2}\right)_{2}(\mathrm{BA})_{2}\left(\mathrm{SO}_{4}\right)_{2}\right]\{\mathrm{M}=\mathrm{Cu}(\mathrm{II})$ or $(\mathrm{Fe}(\mathrm{II})\}$ have been proposed.

The resulted complexes screened for antifungal activity in vitro against the citrus pathogen Aspergillus niger and Fusarium sp. which caused root rot of sugar and the beans pathogen Alternaria sp. All the complexes exhibited significant antifungal activities against these pathogens. The antifungal activity of these complexes were comparable with the standard fungicides in ethanol. The complex $\left[\mathrm{Cu}_{2}\left(\mathrm{ABTSH}_{2}\right)_{2}(\mathrm{BA})_{2} \mathrm{Cl}_{2}\right] \mathrm{Cl}_{2}$ had the best antifungal activity against Alternaria sp.
\end{abstract}

Keywords: Thiosemicarbazone, azine, mixed ligand, copper(II) and iron(II) complex, anti-fungal activity.

\section{INTRODUCTION}

Copper compounds have been used to kill various form of fungi and bacteria. Paints used for ship's hills, contained copper to prevent the excessive growth of marine organisms on the surface of the hull [1]

Thiosemicarbazones comprised a wellknown group of nitrogen and sulfur donors have been extensively used for complex formation [2-4]. This may be due to their capability of acting as multidentate NS, NNS or SNNS donors with the formation of either mono- or bi- or poly-nuclear complexes[5-7]. In addition to their interesting ligational properties, thiosemi-carbazones and their complexes had important catalytical and biological applications [8].

Agood deal of work has been reported on the preparation, spectral and structural investigation of azines and their complexes, due to their capability of acting as multidentate donor [9-12]. Azines and their complexes had important analytical applications, photosensiti-zer in solar cells and biological activities [13,14].

Mixed ligand complexes of transition and non-transition metal ions aroused consider-able interest due to their importance in the field of metalloenzymes and other biological activities $[15,16]$. A good deal of work has been published on their complexes [17-19].

Due to the importance of mixed ligand complexes, we took a modest part in the coordination chemistry of mixed ligand complexes and some articles have been published on their coordination chemistry with transition and non-transition metal ions [20-24].

As decomposers, fungi played an important role in soil formation, but they can also harm crops. Most of the harm they caused occurs during a

* Department of Chemistry, College of Education, University of Mosul

** Plant Protection Department, Faculty of Agriculture and Forestry, Mosul University 
plant's early growth stages. Fungi can also spoil stored food and are particularly devastating to the world's fruit harves [25]. Diseases caused in plants by fungi occerred worldwide, caused considerable damage, typically have been unpredictable and difficult to control culturally or chemically, and host resistance to disease has been inadequate. For these reasons, it is imperative that as much basic knowledge as possible be gained about the taxonomy, biology, physiology, ecology, and host-parasite interactions of these important and devastating plant pathogens to enable us to discover and develop new ways to control them [26].

Pathogenesis is a complex, dynamic process involving the Pathogen's inherent capabilities and multiple factors that govern penetration and infection of a host plant. The host plant has an array of defense mechanisms that must be breached, inactivated, or annulled before disease can develop. This interaction between host and Pathogen also is dependent on the surrounding environment and on time. The Pathogen's battery of attacking mechanisms includes cell wall- and middle lamella-degrading enzymes, toxins, enzymes to degrade host tissue and defense substances, and rapidity of infection. The host can resistant attack by the presence of physical barriers, resistant cell wall materials, performed antifungal compounds, infection-stimulated antifungal compounds, and inadequate nutrients for Pathogen growth and development. If the host responds slowly or inadequately with one or more of these defense mechanisms, disease ensures, and death results [26].

We do know that cell walldegrading enzymes, enzymes capable of destroying cellular components, and production of oxalic acid are associated with disease development.
The exact role of these components in pathogenesis is not clearly defined, but the pieces are beginning to fit together [26].

Since, the power of infecting is shown by the power of penetrating the membranes [cuticle] which are evidently dissolved at the point of penetration. Hence it is very probable that this power depends on the presence of a substance which can dissolve the membrane [26].

Pectolytic enzymes associated with diseases caused. These enzymes have been associated with quantitative decrease in the pectic substances contant of diseased tissue and with histochemical and structural changes in host cell middle lamellae. In addition, pectolytic enzyme activity has been localized in infected tissue. Besides cell wall-degrading enzymes, afew other enzymes such as phosphatidase B capable to hydrolyze phosphatide component of cell membranes. Potentially, proteolytic enzyme responsible for degradation of host protoplasm and possibly cell wall constituents may be detected [26].

The effect of pathogens appears to dependent on a complex combination of factors that can overwhelm the host plant by rapidly acting before the host plant can respond. These factors include: production of infection cushions or appressoria to enable mechanical penetration of the host cuticle, formation of specialized, organized infection hyphae that are capable of rapid intercellular development beneath the host cuticle and in the cortex elaboration of appropriate pectolytic enzymes and oxalic acid to degrade the middle lamella of host cells, chelation-inhibitors of enzyme activity, change the $\mathrm{pH}$ of host tissue to arrange more favorable for enzymeic action, and toxify host cells, making them less responsive to invasion, and 
production of degradative enzymes capable of hydrolyzing cell wall and protoplasmic constituents and providing a constant, abundant supply of nutrients for rapid growth and development of infective hyphae [26].

The antifungal activities of coordinated compounds have been studied by many workers. Complexes of Schiff bases [27], copper [28] and mixed ligands [29] showed a good antifungal activities. Moreover, thiosemicarbazone and their complexes showed a very good antifungal activities [30,31].

In the present work, new copper(II) and iron(II) complexes with mixed ligand \{acetylacetonebis(thiosemicarbazone) and benzaldazine (Figure 1)\} have been prepared and characterized physico-chemically. The complexes were screened for their antifungal activity against Aspergillus niger, Fusarium sp. and Alternaria sp., and they have been exhibited significant antifungal activities.<smiles>CC(CC(C)NNC(N)S)NNC(N)S</smiles>

Figure 1: Structures of the ligands

\section{Material and Methods: \\ 1- Starting Materials}

All the chemicals used were supplied from BDH or Fluka.

\section{2- Synthetic Methods}

Acetylacetonebis(thiosemicarbazone)$\mathrm{ABTSH}_{2}$ has been prepared according to the standard method [32]. Benzaldazine ligand has been prepared according to previous method [32] .

Complexes of the type $\left[\mathrm{Cu}_{2}\left(\mathrm{ABTSH}_{2}\right)_{2}(\mathrm{BA})_{2} \mathrm{Cl}_{2}\right] \mathrm{Cl}_{2}$ has been prepared by the reaction of aqueous solution of copper(II) chloride in $5 \mathrm{ml}$. distilled water $(0.5 \mathrm{~g} ; 0.00186$ mole) with hot ethanolic solution of benzaldazine $(0.00186$ mole $)$ and hot ethanolic solution of 0.00186 mole acetylacetonebis(thiosemicarbazone) in 2:2:2 molar ratio. The mixture has been ref-luxed for three hours followed by evaporation to about half it's volume then cooled. The product was isolated by filteration, washed with diethylether and dried. The other complexes were prepared by applying the same procedure (the amounts in grams were listed in Table 1)

\section{3- Analytical and Physical} Measurements :

Copper and iron contents have been determined by applying precipitation method after the decomposition of the complexes with concentrated nitric acid [33]. Molecular weights of the complexes have been determined cryoscopically (decreasing in freezing point) [34]. Refraction measurements have been carried out with Atago Illumination, 
Atago Co-LTD, Japan using $10^{-3} \mathrm{M}$ dimethylformamide solution. The molar refraction is an additive and constitutive property. It has been used to construct the correct structure of the compound.[34]. The conductivity measurements have been carried out with an electrolytic conductivity measuring set LF-42 using $10^{-3} \mathrm{M}$ dimethylformamide solution at $25{ }^{\circ} \mathrm{C}$. Magnetic susceptibility of the complexes have been measured by Bruker B.M6. The infrared spectra of the ligands and their complexes have been recorded on FTIR Bruker type Tensor 27 in the range 400-4000 $\mathrm{cm}^{-1}$ using $\mathrm{KBr}$ pellets. Electronic spectra has been recorded by Shimadzu UV-1601 Spectrophotometer for $10^{-4} \mathrm{M}$ solutions of the ligands and their complexes in dimethylformamide at $25{ }^{\circ} \mathrm{C}$, using a $1 \mathrm{~cm}$ cell .

\section{4- Antifungal Activity:}

Three microorganism fungi have been selected to study the antifungal activity of the three complexes in this study Aspergillus niger, Fusarium sp., and Alternaria sp. All the fungi have been obtained from Plant Protection Department, Faculty of Agriculture and Forestry, Mosul University.

The fungi were isolated from the affected plants by applying Agnihorti method [35] and purified using classification keys that were put by Barrutt and Hunter [36]. The antifungal activity has been evaluated by applying Al-Khafaf method [37] that depended on Abbott method [38] as follows:

$0.1 \mathrm{gm}$ of the complex was dissolved in $100 \mathrm{ml}$. ethanol $(95 \%)$. 1 $\mathrm{ml}$. of this solution was added to sterilized petrydish containing Potato Dextrose Agar (PDA) which was left for one day $(24 \mathrm{hr}$.) until the ethanol was evaporated A part of a side of the colony (4 days age growing) was inoculated in the center of the sterilized dish above. The dish was incubated at $25 \pm 3{ }^{\circ} \mathrm{C}$ for $5-6$ days and the inhibition zone was measured. In all the experiments the mean of each triplicate was measured. Blank dish of ethanol $(95 \%)$ has been used as control.

\section{RESULTS AND DISCUSSION}

The reaction of copper (II) and iron(II) salts with acetylacetonebis (thiosemicarbazone and benzaldazine may be represented by the following reactions :

$2 \mathrm{CuCl}_{2}+2 \mathrm{BA}+2 \mathrm{ABTSH}_{2} \rightarrow$

$\left[\mathrm{Cu}_{2}\left(\mathrm{ABTSH}_{2}\right)_{2}(\mathrm{BA})_{2} \mathrm{Cl}_{2}\right] \mathrm{Cl}_{2}$

$2 \mathrm{MSO}_{4} \cdot \mathrm{nH}_{2} \mathrm{O}+2 \mathrm{BA}+2 \mathrm{ABTSH}_{2} \rightarrow[\mathrm{M}$
$\left.(\mathrm{ABTSH})_{2}(\mathrm{AB})_{2}\left(\mathrm{SO}_{4}\right)_{2}\right]+\mathrm{nH}_{2} \mathrm{O}$
(where $\mathrm{n}=5$ or 7$).$
$\quad$ The resulted complexes were colored solid. Copper, iron contents and the molecular weights revealed that the complexes had the compositions

$\left[\mathrm{Cu}_{2}\left(\mathrm{ABTSH}_{2}\right)_{2}(\mathrm{BA})_{2} \mathrm{Cl}_{2}\right] \mathrm{Cl}_{2}$ and $\left.\left[\mathrm{M}(\mathrm{ABTSH})_{2}\right)_{2}(\mathrm{AB})_{2}\left(\mathrm{SO}_{4}\right)_{2}\right]$ (Table 2). The values of the molar conductivities of the complex-es (Table 2) approached those expected for 1:2 and non-elecotrolytes [39]. The room temperature magnetic moment of $\mathrm{Cu}$ (II) complexes lied in the range of 1.82-1.88 which were compared to the expected values for six coordinate high-spin octahedral complexes[22]. The magnetic moment of iron(II) complex has been found to be 5.10 B.M. which is within the range of values corresponding to high spin octahedral complexes of iron(II) ions [20] (Table 2).

The infrared spectra of $\mathrm{ABTSH}_{2}$ ligand (Table 3) showed a strong band at $1635.58 \mathrm{~cm}^{-1}$ assigned to $\mathrm{C}=\mathrm{N}$ group shifted towards a lower frequency on coordination due to the decrease of the bond order as a result of metal nitrogen bond formation [40]. The next strong band at $1200.25 \mathrm{~cm}^{-1}$ and $1169.12 \mathrm{~cm}^{-1}$ attributed to the 
stretching and bending frequencies of $\mathrm{C}=\mathrm{S}$ group. The first value splitted into two peaks one remained at the same position and the other shifted towards a lower frequency on coordination, indicating the formation of chelation between the sulfur of one $\mathrm{C}=\mathrm{S}$ group and the metal ion [40]. The other strong bands at $3399.04 \mathrm{~cm}^{-1}$ and $1450.00 \mathrm{~cm}^{-1}$ attributed to $v_{\mathrm{NH} 2}$ and $\partial_{\mathrm{NH} 2}$ remained unaltered in all the complexes indicating that there is no coordination through this group [21,29,30].

The spectra benzaldazine showed a strong band in the region $1624.00 \mathrm{~cm}^{-1}$ due to $\mathrm{C}=\mathrm{N}$ stretching vibration group [40]. This band was shifted towards a lower frequency (Table 3) which demonstrated that the two azine nitrogen was coordinated to the metal ion[40]. Moreover, the positive shift in the N-N vibration band on complexation can be added as further support to the coordination of the azine nitrogen to the metal ion.

The spectra of complex 1 showed a new band at $525.50 \mathrm{~cm}^{-1}$ attributed to ionic $\mathrm{M}-\mathrm{Cl}$ [40], whereas

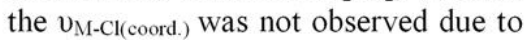
instrumental limitation. The spectra of the complexes 2 and 3 showed three bands around 1010.00, 1073.00 and $1125.00 \mathrm{~cm}^{-1}$ due to SO group [40] indicating that the sulphato group acted as monodentate ligand bonding to the metal ion through the oxygen atom [40].

On the other hand the spectra of all the complexes showed new bands around $450.82-456.45 \mathrm{~cm}^{-1}$ and $556.62-$ $558.27 \mathrm{~cm}^{-1}$ due to $v_{\mathrm{M}-\mathrm{N}}$ and $v_{\mathrm{M}-\mathrm{S}}$, respectively $[17,21,31]$. The presence of these bands supported the formation of the complexes under investigation.

The electronic spectra of the complexes in DMF solution have been recorded giving ultraviolet spectra, $d-d$ spectra and charge transfer spectra (Table 4). The ultraviolet spectra for
$\mathrm{ABTSH}_{2}$ showed bands at $39550 \mathrm{~cm}^{-1}$ and $26178 \mathrm{~cm}^{-1}$ attributed to $\mathrm{n} \rightarrow \pi^{*}$ and $\pi \rightarrow \pi^{*} \quad$ electronic transitions, respectively. The ultraviolet spectra for BA ligand showed bands at $38750 \mathrm{~cm}^{-1}$ and $27941 \mathrm{~cm}^{-1}$ attributed to $\mathrm{n} \rightarrow \pi^{*}$ and $\pi \rightarrow \pi^{*} \quad$ electronic transitions, respectively. All these transitions were also found in the spectra of the complexes but they were shifted to lower frequencies $\left(\Delta v=1700-2000 \mathrm{~cm}^{-}\right.$ $\left.{ }^{1}\right)$ confirming the coordination of the ligands to the metal ions[41]. The electronic spectra of $\mathrm{Cu}$ (II) complex showed a band at 13835 and $13850 \mathrm{~cm}^{-}$ ${ }^{1}$ which may be assigned to ${ }^{2} \mathrm{Eg} \rightarrow{ }^{2} \mathrm{~T}_{2} \mathrm{~g}$ transition in an octahedral environment. The eg group state is highly susceptible to John-Teller configurational stability due to which copper (II) ion in the complexes had distorted octahedral geometry. The electronic spectra of copper(II) complexes also showed a band at 31200 and $31215 \mathrm{~cm}^{-1}$ due to charge transfer spectra[42]. The electronic spectra of $\mathrm{Fe}(\mathrm{II})$ complex is a characteristic of an octahedral geometry having high spin electronic configuration. According to this electronic distribution, only one welldefined $\quad{ }^{5} \mathrm{~T}_{2} \mathrm{~g} \rightarrow{ }^{5} \mathrm{Eg}$ transition However, due to the Jahn Teller effect, the ${ }^{5} \mathrm{Eg}$ term is split in two terms which are responsible for the occurrence of a band and a shoulder in the spectrum. Hence $\mathrm{Fe}$ (II) complex showed a pair of low intensity bands at 12500 and $10210 \mathrm{~cm}^{-1}$, arising from ${ }^{5} \mathrm{~T}_{2} \mathrm{~g} \rightarrow{ }^{5} \mathrm{~A}_{1} \mathrm{~g}$ and $\quad{ }^{5} \mathrm{~T}_{2} \mathrm{~g} \rightarrow{ }^{5} \mathrm{~B}_{1} \mathrm{~g}$, transitions similar to those found for distorted octahedral complexes. The doublet is attributed to a Jahn Teller distortion in the excited state [42]. The electronic spectra of iron(II) complex also showed a band at $35200 \mathrm{~cm}^{-1}$ due to charge transfer spectra [42].

It is well known that in order to the antifungal activity to be effective the antifungal compounds must have 
ability to penetrate inside the fungi cell ( some times the antifungal compounds caused changes in the medium in which the fungi was grown and made it unsuitable for the growth of the fungi).

After the antifungal compound was penetrated through the protoplasmic membrane of the fungi, the compound started to did it's toxic effect inside the fungi cell. Some antifungal compounds may increase the resistance of the host plant in a way that can made changes in the cell wall tissue of the plant and made it very difficult to be penetrated by the fungi that caused the diseases. There are numbers of explanations that can allow the antifungal compound to does it's toxic effects including the following points:

1- Reaction of antifungal compound with the vital enzymes and inhibited them.

2- Influence the oxidation-reduction reaction which affect the production of energy.

3- Influence the vital processes through the similar composition of some antifungal compound with the compound exist in fungi cell, therefore it can enter wrongly in a numer of vital reactions and sometimes can led to the death of fungi.

4- The antifungal compound may interacts with some vital compounds, this can influence the vital immunity of the compound which the fungi cell needed. The reaction with some amino acids may influence the process of protein synthesis [43]

The activity of the prepared compounds were compared with other known antifungal compounds(dodine and rovral used as antifungal for Alternaria sp., and benlate used as antifungal for Aspergillus niger and Fusarium sp.).

The complex

$\left[\mathrm{Cu}_{2}(\mathrm{ABTSH})_{2}(\mathrm{BA})_{2} \mathrm{Cl}_{2}\right] \mathrm{Cl}_{2}$ showed a good antifungal activity against
Aspergillus niger and Alternaria sp., but very low activity against Fusarium sp. While the complex $\left.\mathrm{Cu}_{2}\left(\mathrm{ABTSH}_{2}\right)_{2}(\mathrm{BA})_{2}\left(\mathrm{SO}_{4}\right)_{2}\right]$ showed a good antifungal activity against only Aspergillus niger but no activity against the other two fungi (Fusarium sp. and Alternaria sp.). Whereas the complex $\left[\mathrm{Fe}_{2}(\mathrm{ABTSH})_{2}(\mathrm{BA})_{2}\left(\mathrm{SO}_{4}\right)_{2}\right]$ showed a good antifungal activity against only Aspergillus niger and Alternaria $s p$, but very low activity against Fusarium sp.

\section{CONCLUSSION}

According to the analytical, physical and spectral studies, the following observations have been achieved that lead to establish the following points:

1- The ligand $\mathrm{ABTSH}_{2}$ acted as tridentate chelating bridging ligand joint to the metal ion through the two azomethine nitrogen and one thiosulfur.

2- The ligand BA acted as bridging ligand joint through the two nitrogen atoms.

3- The chloride ion acted as monodentate ligand and also as countert ion in complex 1.

4- Sulfate ion acted as monodentate ligand joint through oxygen atom

5- Copper(II) and iron(II) ions had hexacoordinated resulting in a high spin distorted octahedral geometry. From the present study we can concluded that the complexes had the following proposed geometries(Figure 2).

6- The complexes showed good antifungal activity against Aspergillus niger and Alternaria sp., whereas no or very low activity against Fusarium sp. The complex $\left[\mathrm{Cu}_{2}\left(\mathrm{ABTSH}_{2}\right)_{2}(\mathrm{BA})_{2} \mathrm{Cl}_{2}\right] \mathrm{Cl}_{2}$ showed best antifungal activity against Alternaria sp. 


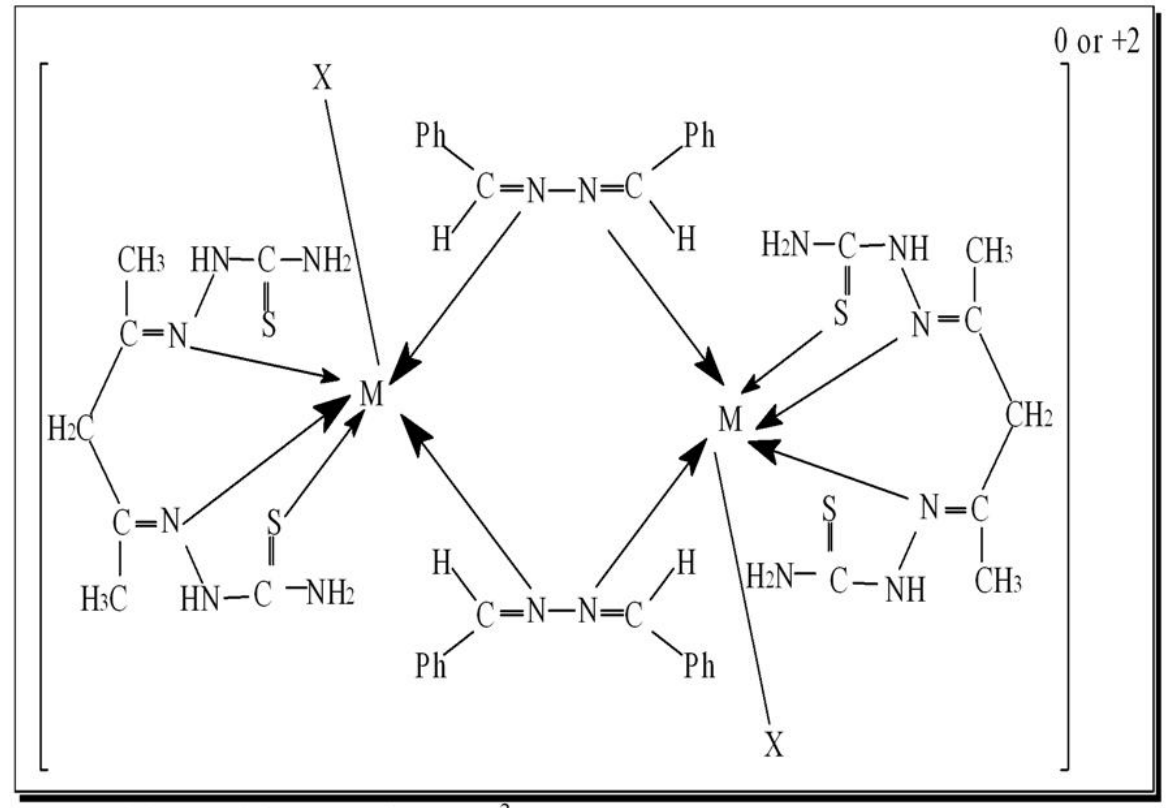

$\mathrm{M}=\mathrm{Cu}(\mathrm{II})$ or $\mathrm{Fe}(\mathrm{II}) ; \mathrm{X}=\mathrm{Cl}^{-}$or $\mathrm{SO}_{4}^{-2}$

Figure 2 : Proposed structures of the complexes

Table 1 : Amounts of ligands, \%yield of the complexes

\begin{tabular}{|c|c|c|c|c|}
\hline No. & Complexes & $\begin{array}{c}\text { Wt of } \mathbf{A B T S H}_{2} \\
(\mathbf{g m})\end{array}$ & $\begin{array}{c}\text { Wt of BA } \\
(\mathbf{g m})\end{array}$ & \%Yield \\
\hline 1 & {$\left[\mathrm{Cu}_{2}\left(\mathrm{ABTSH}_{2}\right)_{2}(\mathrm{BA})_{2} \mathrm{Cl}_{2}\right] \mathrm{Cl}_{2}$} & 0.9145 & 0.7732 & 90.2 \\
\hline 2 & {$\left[\mathrm{Cu}_{2}\left(\mathrm{ABTSH}_{2}\right)_{2}(\mathrm{BA})_{2}\left(\mathrm{SO}_{4}\right)_{2}\right]$} & 0.4930 & 0.4168 & 89.9 \\
\hline 3 & {$\left[\mathrm{Fe}_{2}\left(\mathrm{ABTSH}_{2}\right)_{2}(\mathrm{BA})_{2}\left(\mathrm{SO}_{4}\right)_{2}\right]$} & 0.4424 & 0.3741 & 87.5 \\
\hline
\end{tabular}

Table 2: Analytical and physical properties of the complexes

\begin{tabular}{|c|c|c|c|c|c|c|c|}
\hline No. & Color & $\begin{array}{c}\text { M.P } \\
{ }^{\mathbf{c}}\end{array}$ & ${ }^{*}{ }_{\mathbf{M}}$ & ${ }^{*} \mathbf{M}_{\text {eff. }}$ & $\begin{array}{c}\text { Ref. } \\
\mathbf{x 1 0}\end{array}$ & $\begin{array}{c}\text { M\% } \\
\text { Calc. Obs. })\end{array}$ & $\begin{array}{c}\text { M. Wt. } \\
\text { Calc. (Obs.) }\end{array}$ \\
\hline 1 & Green & $204 \mathrm{~d}$ & 135.5 & 1.82 & 1.435574 & $10.79(10.72)$ & $1177(1190)$ \\
\hline 2 & $\begin{array}{c}\text { Dark } \\
\text { green }\end{array}$ & $166 \mathrm{~d}$ & 11.4 & 1.88 & 1.435571 & $10.35(10.38)$ & $1227(1233)$ \\
\hline 3 & $\begin{array}{c}\text { Dark } \\
\text { Green }\end{array}$ & 220 & 6.5 & 5.10 & 1.435577 & $9.24(9,20)$ & $1212(1202)$ \\
\hline
\end{tabular}

${ }^{*} \Lambda_{\mathrm{M}}$ : Molar conductivities in $\Omega^{-1} \mathrm{~cm}^{2} \mathrm{~mol}^{-1}$; ${ }^{* *} \mu_{\text {eff }}$ : Magnetic moment in Bohr Magneton; $\mathrm{d}=\mathrm{dec}$ emposition points; Ref.= refraction

Table 3 : IR spectra of complexes (values in $\mathbf{c m - 1}$ )

\begin{tabular}{|c|c|c|c|c|c|c|c|c|}
\hline No. & $v_{\mathrm{C}=\mathrm{N}}$ & $v_{\mathrm{C}=\mathrm{S}}$ (thio) & $v_{\mathrm{NH}}$ & $\delta \mathrm{NH}_{2}$ & $\begin{array}{c}v_{\mathrm{C}=\mathrm{N}} \\
\text { (azine) }\end{array}$ & $v_{\mathrm{N}-\mathrm{N}}$ & $v_{\mathrm{M}-\mathrm{N}}$ & $\mathbf{v}_{\mathrm{M}-\mathrm{S}}$ \\
\hline $\mathrm{ABTSH}_{2}$ & 1635.00 & 1200.25 & 3399.04 & 1450.00 & - & - & - & - \\
\hline BA & - & - & - & 1455.00 & 1624.00 & 950.00 & - & - \\
\hline 1 & 1600.54 & $1200.25,1145.54$ & 3400.20 & 1455.00 & 1556.21 & 980.20 & 450.82 & 558.27 \\
\hline 2 & 1601.59 & $\begin{array}{l}1200.25 \\
1142.50\end{array}$ & 3399.05 & 1455.00 & 1558.05 & 982.50 & 451.00 & 556.62 \\
\hline 3 & 1602.24 & $1200.25,1150.35$ & 3399.45 & 1455.00 & 1556.25 & 983.50 & 456.45 & 557.35 \\
\hline
\end{tabular}


Table 4 : Electronic spectral data of the ligands and their complexes

\begin{tabular}{|c|c|c|c|c|c|}
\hline \multirow{2}{*}{ No. } & \multicolumn{2}{|c|}{ UV region } & \multicolumn{2}{|c|}{ d-d transition } & \multirow{2}{*}{$\begin{array}{l}\text { C.T } \\
\mathrm{cm}^{-1}\end{array}$} \\
\hline & $\pi \rightarrow \pi^{*}$ & $\mathbf{n} \rightarrow \pi^{*}$ & $v_{1} \mathrm{~cm}^{-1}$ & $v_{2} \quad \mathrm{~cm}^{-1}$ & \\
\hline $\mathrm{ABTSH}_{2}$ & 39550 & 26178 & & & \\
\hline $\mathrm{BA}$ & 38750 & 27941 & & & \\
\hline 1 & 37800,37050 & 24378,25191 & 13835 & & 31200 \\
\hline 2 & 37550,36750 & 244750,26241 & 13850 & & 31215 \\
\hline 3 & 37750,36750 & 24175,25940 & 12500 & 10210 (shoulder) & 35200 \\
\hline
\end{tabular}

Table 5: Antifungal activity of the complexes

\begin{tabular}{|c|c|c|c|c|c|c|c|c|c|c|c|c|}
\hline \multirow[b]{2}{*}{ Comp. No. } & \multicolumn{4}{|c|}{ Aspergillus niger } & \multicolumn{4}{|c|}{ Fusarium sp. } & \multicolumn{4}{|c|}{ Alternaria sp. } \\
\hline & Trip. & Dia. & Inh. $\%$ & mean $\%$ & Trip. & Dia. & Inh. $\%$ & mean $\%$ & Trip. & Dia. & Inh. $\%$ & mean $\%$ \\
\hline \multirow{3}{*}{1} & 1 & 0.00 & 100.00 & \multirow{3}{*}{85.83} & 1 & 1.75 & -20.69 & \multirow{3}{*}{5.75} & 1 & 0.00 & 100.00 & \multirow{3}{*}{100.00} \\
\hline & 2 & 1.70 & 73.23 & & 2 & 1.15 & 20.69 & & 2 & 0.00 & 100.00 & \\
\hline & 3 & 1.00 & 84.25 & & 3 & 1.20 & 17.25 & & 3 & 0.00 & 100.00 & \\
\hline \multirow{3}{*}{2} & 1 & 0.95 & 85.04 & \multirow{3}{*}{87.14} & 1 & 1.40 & 3.45 & \multirow{3}{*}{-8.05} & 1 & 0.50 & 43.18 & \multirow{3}{*}{-7.95} \\
\hline & 2 & 0.00 & 100.00 & & 2 & 1.50 & -3.45 & & 2 & 0.95 & -7.95 & \\
\hline & 3 & 1.50 & 76.38 & & 3 & 1.80 & -24.14 & & 3 & 1.40 & -59.09 & \\
\hline \multirow[b]{3}{*}{3} & 1 & 1.20 & 81.10 & \multirow{3}{*}{78.74} & 1 & 1.45 & 0.00 & \multirow{3}{*}{5.75} & 1 & 0.70 & 20.45 & \multirow{3}{*}{73.48} \\
\hline & 2 & 1.30 & 79.53 & & 2 & 1.55 & -6.90 & & 2 & 0.00 & 100.00 & \\
\hline & 3 & 1.55 & 75.59 & & 3 & 1.10 & 24.14 & & 3 & 0.00 & 100.00 & \\
\hline \multicolumn{2}{|l|}{ St. I } & 6.35 & & & & & & & & & & \\
\hline
\end{tabular}

Dia. $=$ Average of two perpendicular diameter of the fungi colony; Inh. $=$ inhibition zone

\section{REFERENCES}

1- A. Stwertka, A guide to the elements; Oxford Univ., Press, Inc., Perlin, Rev. ed., 93 (1998).

2- B. Singh and H. Misra; Complexes of cobalt(II), copper(II), zinc(II), cadmium(II) and dioxouranium(II) with thiophene-2aldehydethiosemicarbazone; J. Indian Chem. Soc.; 63: 692-694 (1986).

3- W. Kaminsky, J.P. Jasinski, R. Noudenberg, K.I. Goldberg and D.X. West; Structural study of two N(4)-substituted thiosemicarbazones prepared from 1-phenyl-1,2-propanedione-2oxime and their binuclear nickel(II) complexes; J. Mol. Struct.; 135141.5-H(2002).

4- F.A. El-Saied, A.A. El-Asmy, W. Kaminsky and D.X. West; Spectral and structural studies of cobalt(II,III), nickel(II) and copper(II) complexes of de hydroaceticacid $\mathrm{N}_{4}$-dialkyl and 3azacyclothiosemicarbazones;
Trans. Met. Chem.; 28:954-960 (2003)

5- Z.H. Chohan, H. Pervez, K.M. Khan, C.T. Supuran; Organometallic-based antibacterial and antifungal compounds: transition metal complexes of 1,1 diacetylferrocene derived thiocarbo-hydrazone, carbohydrazone, thiosemicarbazone and semicarbazone; J.Enzym Inhib. Med. Chem.; 20(1): 81-88 (2005).

6- M.C. Aguirre, J. Borrãs, A. Castifieiras, J.M. GurciaMonteagudo, I. Garcia-Santos, J. Niclõs and D.X. West; Synthesis, characterization, and properties of some copper complexes of 2pyridineformamidethiosemicarbazo ne $\left(\mathrm{Ham}_{4} \mathrm{DH}\right)$; European J. Inorg. Chem.; 1231-1244 (2006)

7- V.M. Leovac, L.S. Jovanovic, V. Divjakovic, A. Pervec, I. Lebnan and $\mathrm{Tr}$. Armbruster; Transition metal complexes with thiosemicarbazide-based ligandpart LIV-nickel(II) complex-es 
with pyridoxalsemicarbazone (PLSC) and thiosemicarbazone (PLTSC) crystal and molecular structure

$\left[\mathrm{Ni}(\mathrm{PLSC})\left(\mathrm{H}_{2} \mathrm{O}\right)_{3}\right]\left(\mathrm{NO}_{3}\right)_{2} \quad$ and [Ni(PLTSC-H)Py] $\mathrm{NO}_{3}$;

Polyhedron; 26(1): 49-58 (2007).

8- B.K. Rai, K. Kumer and Y.P. Srivastava; Spectroscopic

9- S. Satapathy and Sahoo.; Salicylaldazinate metalchelates and their IR. Spectra; J. Inorg. Nucl. Chem;. 23: 2223-2227 (1970).

10- R.C. Aggarwal, N. K. Singh and R.P. Singh; Synthesis and structural studies of salicylaldazine complexes of oxovanadium(IV), manganese(II), Iron(II), Cobalt(II), nickel(II), copper (II) and zinc(II); J. Indian Chem. Soc.; LXIII: 466468 (1986)

11- W. Dinkn, N. Megersa, V.J.T. Raju, J.A. Jonsson and N. Retla; Studies of transition metal complexes of herbicidal compounds 1: Transition metal complexes of 2-methylthio-4azido-6-isopropylamino-S-triazine (aziprotryn); Bull. Chem. Soc. Ethiopia, 15: (1), 29-38 (2003).

12- B. Singh and U.R. Singh; Synthesis and structural characterization of 2aminoacetophe-nones salicyldazine complexes of some bivalent transition metal ions; Cryst. Res. Tech.; 26: (8), 1039-1045 (2006).

13- S.D. Perera, B.L. Shaw and M. Thornton-Pett.; Agerieral strategy for inducing $\mathrm{C}-\mathrm{H}$ bond fission (cycloiridation) in some aryl heterocyclic, alkenyl or alkyl groups in azine derived from aldehydes or methyl ketone; $J$.

19- B.K. Choudhary, P. Sahi and S. Rana; Structural characterization and antifungal studies of some mixed ligand Schiff base investigation and antifungal studies of some mixed ligand complexes of $\mathrm{Co}(\mathrm{II}), \mathrm{Ni}(\mathrm{II})$ and $\mathrm{Cu}(\mathrm{II})$ with 6methyl-2-

pyridylformamidesemicarbazone and thiosemicarbazone; Asian J. Chem.; 17(3): 1773-1779 (2005).

Chem. Soc. Dalton Trans,; 1689 (1995)

14- Kalyanasundaram K.; Use of azine dye as a photosensitizer in solar cell: Different reductants-safranine; Int. J. Enorgy Res.; 21: (14), 13451350 (1997).

15- M.M. Ajaily, A.A. Maihub, S.F. Ben-Gweirif, A.M. Belazi and R.S. El-Zweay; Chara-cterization and antibacterial activity of $\mathrm{Mn}(\mathrm{II})$, $\mathrm{Fe}(\mathrm{III}), \mathrm{Co}(\mathrm{II}), \mathrm{Ni}(\mathrm{II}), \mathrm{Cu}(\mathrm{II})$ and $\mathrm{Zn}$ (II) mixed ligand complexes; Orient. J. Chem.; 23: 1 (2007).

16- B.K. Rai, K. Kumar and Y.P. Srivastava; Spectroscopic investigation and antifungal studies of some mixed ligand complexes of $\mathrm{Co}(\mathrm{II}), \mathrm{Ni}(\mathrm{II})$ and $\mathrm{Cu}(\mathrm{II})$ with 6methyl-2-pyridyl-formamide semicabazone and thiosemicarbazone; Asian J. Chem.; 17: (3), 1773-1779 (2005).

17- P. Bindu, M.R.P. Kurup and T.R. Satyakeerty; EPR, cyclic voltametric and biological studies of copper(II) complexes of salicylaldehyde N(4) substituted thiosemicarbazone and heterocyclic bases; Polyhedron, 18, 321(1998).

18- R. Ramesh and M. Sivamasundari; Synthesis, spectral and antifungal activity of mixed ligand complexes; Synth. React. Inorg. Met-Org. Chem.; 33(5), 899-910 (2003).

complexes with 6-bromo-2-thio-3phenylquinazoline $4(3 \mathrm{H})-$ onethiosemicarbazone; Oriental $\mathrm{J}$. Chem.; 23, 1 (2006). 
20- Z. F. Dawood \& A.A. Mohamad; Preparation and characterization of $\mathrm{Fe}(\mathrm{II})$ complexes containing mixed ligands; Al-Taqani; 19(2), 100108(2006)

21- Z. F. Dawood \& A. Y. Ritha; Preparation of binuclear complexes; R. J. of Aleppo Univ. Basic Sciences Series; 54 (2007)

22- Z. F. Dawood and Y. T. Mahmood, Preparation and radiolysis of new mixed ligand copper(II) complexes; J. Of Col. Of B. Ed.; 51, 13-28 (2007).

23- Z. F. Dawood and M.W. Ibrahim, Preparation of some nickel(II) complexes containing mixed ligands (salicylaldehydesemicarbazone) and carboxylic acids; Nat. J. Chem.; 30, 330-337(2008).

24- Z. F. Dawood, T.J. Mohammed and M.R. Sharif; New nickel(II) complexes with benzilbis(semicarbazone) \& dithiocarbamate ligands; Iraqi $\mathbf{J}$. Veterinary Sci.; 23(II), 135-141 (2009).

25- J. Suchocki; Conceptual chemistry: Understanding our world of atoms and molecules; Fungicides kill funge; Addison Wesley, United States, 506-507 (2001).

26- R.D. Lumsden; Histology and physiology of pathogenesis in plant diseases caused by Sclerotinia Species; Phytopathoogy;; 69(8), 890-896 (1979).

27- G.I. Devi, G. Parameswaran and S.S. Veena; Antifungal studies of complexes of Schiff base derived from anthracene carboxaldehydeL-tyrosin; Asian J. Chem.; 16(2), 884-890 (2004).

28- B. Dudová, D. Hudecová, R. Pokorný, M. Micková, M. Palicová, P. Segla and M. Melnik; Copper complexes with bioactive ligands. Part II; Antifungal activity;
Folia Microbiol.; 47, 225-229 (2002).

29- R. Ramesh and M. Sivagamasundari; Synthesis, spectral and antifungal activity of mixed ligand complexes; Synth. React. Inorg. Met.-Org. Chem.; 33(5), 899-910 (2003).

30- E. Bermejo, R. Carballo, A. Castineiras, R. Domnguez, C. Maichle-Mossmer, J. Strahle and D.X. West; Synthesis, characterization and antifungal activity of group 12 metal complexes of 2-acetylpyridine$\wedge 4 \mathrm{~N}$-ethylthiosemicarbazone (H4EL) and 2-acetylpyridine-Noxide- $\wedge$ 4 -ethylthiosemicarbazone (H4ELO); Polyhedron; 18(27), 3695-3702 (1999).

31- M.A. Ali, M.H. Kabir, M.N. Uddin, S.M.M. Majumder, M.T.H. Tarafder and M.A. Khair; Synthesis, characterization and antifungal properties of some fourcoordinate nickel(II) and four and five coordinate copper(II) complexes containing tridentatethiosemicarba-zone and heterocyclic bases; Indian J. Chem.; 27A, 1064 (1988).

32- A.I. Vogel; Textbook of Practical Organic Chemistry; Longman Green, London, $3^{\text {rd }}$ ed., 344 (1964).

33- A. I. Vogel; Textbook of Quantitative Inorganic Analysis; Longman Green, London, $3^{\text {rd }}$ ed., (1978).

34- J. W. Danials; Experimental Physical Chemistry; McGraw-Hill, $6^{\text {th }}$ ed., 81 (1962)

35- V.P. Agnihorti; Effects of certain fungi toxicants on the viability and pathogenicity of sclerotia of waitea circinata phytopath; 70, 7180 (1971).

36- H.L. Barnett and B.B. Hunter; Illustrated genera of imperfect fungi. American Phytopathological Society 3340 Pilot 
knob road st Paul Minnesota 55121-2097.USA, 217P (2003).

37- W,A.Y. Al-Khafaf; Ecological and biological studies on the poplar clearwing moth Eusphecia pimplaeformis Ob.(Aegeriidae Lepidoptera) and it's control; $\mathrm{Ph}, \mathrm{D}$., Mosul University, College of Agriculture and Forestry (1999).

38- W.S. Abbott; A method of computing the effectiveness of an insecticides; J. Econom. Entomol; 18, 265-267(1925)

39- W. J. Geary; Use of conductivity measurements in organic solvents for the characteriza-tion of coordination compounds; Coord. Chem. Rev. , 7, 81-87(1971).
40- K. Nakamoto, "Infrared and Raman Spectra of Inorganic and Coordination Compound", John Wily and Sons, New York, $3^{\text {rd }}$ ed., (1976).

41- A.I. Scott; Interpretation of the ultraviolet spectra of natural products; Pergamon Student ed., (1964)

42- D. Sutton; "Electronic Spectra of transition metal complexes", McGraw-Hill publishing Co., London; (1968).

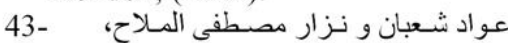

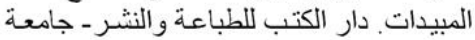
الموصل، 188-189 ، 206 211، 211، (1993 )

\section{الفعالية مضادة الفطريات لبعض المعقدات ثنائية النواة الجديدة

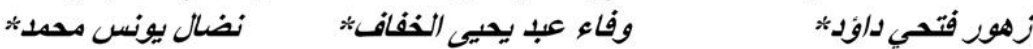 \\ "قالكم الكيمياء/كلية التربية /جامعة الموصل.

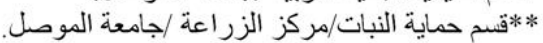 \\ الخلاصة}

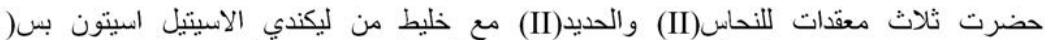

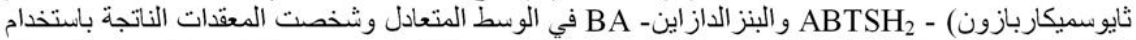

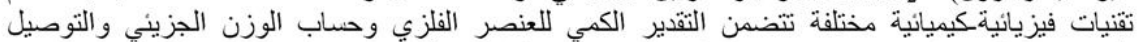

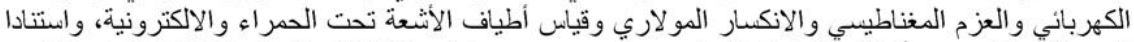
الى ذلك إقترحت أثنكال ثمانية النطوح ذات صيغ عامة ( للمعقدات الناتجة.

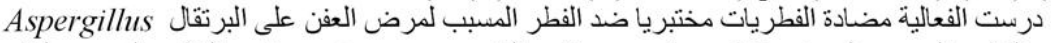

niger

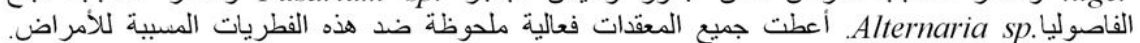

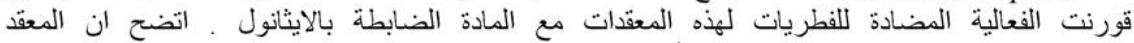

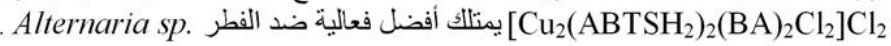

